\title{
Geochemistry of peridotitic clinopyroxene from the diamondiferous Mbuji-Mayi and Tshibwe kimberlites (DRC): Insight into the compositional and thermal State of the SCLM beneath the northeastern Kasai Craton
}

\author{
B. Jaziel Nkere ${ }^{1 *}$, Philip E. Janney ${ }^{1}$ \\ ${ }^{1}$ Department of Geological Sciences, University of Cape Town, Rondebosch 7701, South Africa
}

\section{Introduction and major element systematics}

The composition of clinopyroxenes from heavy mineral concentrates of the diamondiferous Mbuji-Mayi and Tshibwe kimberlites in the DRC have been studied to constrain the thermal and compositional state of the lithospheric mantle underlying the northeastern section of the Archaean Kasai craton of central Africa. Clinopyroxenes from Mbuji-Mayi fall into two populations, a larger subcalcic group (group 1; with Ca\# between 41 and 45) and a smaller calcic group (group 2; with Ca\# between 45 and 47) with group 2 cpx showing overall lower $\mathrm{Al}_{2} \mathrm{O}_{3}$ values and a trend of decreasing $\mathrm{Al}_{2} \mathrm{O}_{3}$ with increasing Ca\# (Fig. 1). The group $1 \mathrm{cpx}$ show an increase in $\mathrm{Al}_{2} \mathrm{O}_{3}$ contents with increasing Ca\#. Both groups are relatively $\mathrm{Cr}$-rich (Cr\# ranging between 17.7 and 69.1) with group 1 having higher $\mathrm{Cr}$ contents, but they both show a broad increase of $\mathrm{Cr} \#$ with increasing $\mathrm{Mg \#}$, and both groups display a broad range of $\mathrm{Mg} \#$ (from 88.5 to 94 with group $2 \mathrm{cpx}$ having higher $\mathrm{Mg} \#$ on average than group 1). Both groups have high $\mathrm{Na}_{2} \mathrm{O}$ contents (ranging between 1.5 to 3.6 wt \%) with group 1 extending to higher $\mathrm{Na}_{2} \mathrm{O}$ contents. Contents of $\mathrm{TiO}_{2}$ and $\mathrm{Na}_{2} \mathrm{O}$ decrease with increasing Ca\# in group 2 while no correlation is observed in group 1.

Clinopyroxenes from the Tshibwe kimberlite are very similar to the Mbuji-Mayi group 2 clinopyroxenes in terms of their major element compositions. However, they extend to slightly higher $\mathrm{Ca} \#$ values $(44-48)$ and lower $\mathrm{Al}_{2} \mathrm{O}_{3}$, lower $\mathrm{TiO}_{2}\left(0.22-0.05\right.$ wt.\%) and lower $\mathrm{Na}_{2} \mathrm{O}(1.7-1.18$ wt.\%) than Mbuji-Mayi clinopyroxenes.

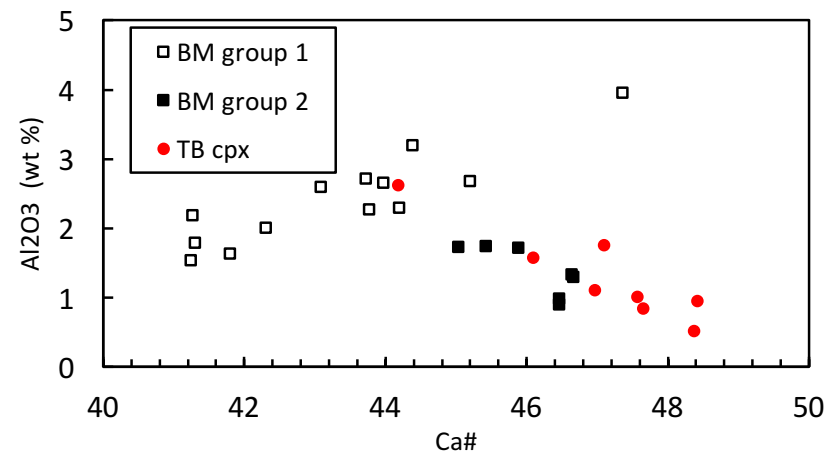

\begin{abstract}
Figure 1: $\mathrm{Ca} \#(\mathrm{Ca} /(\mathrm{Ca}+\mathrm{Mg})$ in atomic units) plotted versus wt. $\% \mathrm{Al}_{2} \mathrm{O}_{3}$ in peridotitic clinopyroxenes from concentrate from Mbuji-Mayi (BM groups 1 and 2) and Tshibwe (TB). Note the distinct trends formed by the BM group 1 and TB data.
\end{abstract}

Trace element and $\mathrm{Sr}$ isotope systematics

Trace element patterns of Mbuji-Mayi group 1 and group 2 clinopyroxenes are similar. They show fairly uniform convex upward and LREE enriched REE patterns with group $1 \mathrm{cpx}$ extending to greater extents of LREE enrichment than group $2 \mathrm{cpx}\left((\mathrm{Nd} / \mathrm{Yb})_{\mathrm{N}}=22.1-100.1\right.$ and $22.5-55.1$ for group 1 and group 2, respectively). Both group 1 and $2 \mathrm{cpx}$ show relative depletions in $\mathrm{Ba}, \mathrm{Pb}, \mathrm{Zr}$ and Ti relative to elements of similar incompatibility, but the depletions in Group 1 are stronger (Fig. 2c).

Trace element patterns of Tshibwe clinopyroxenes are very similar to Mbuji-Mayi group 2 clinopyroxenes, but with slightly less LREE-enrichment on average (most Tshibwe cpx have $(\mathrm{Nd} / \mathrm{Yb})_{\mathrm{N}}$ ratios between 30.5 and 38.7). However one Tshibwe cpx grains have anomalously high $(\mathrm{Nd} / \mathrm{Yb})_{\mathrm{N}}$ value of 150.5 with $(\mathrm{Sc} / \mathrm{V})_{\mathrm{N}}$ ratios lower than unity $(0.87$; Fig. 2a).

Clinopyroxenes from Mbuji-Mayi and Tshibwe span nearly identical ranges of measured ${ }^{87} \mathrm{Sr} /{ }^{86} \mathrm{Sr}$ (with ranges of $0.7031-0.7052$ and $0.7035-0.7053$, respectively), falling within the range of Group I kimberlites (including Mbuji-Mayi; Weis \& Demaiffe, 1985) and PIC rocks (as summarised by Grégoire, 2002). 


\section{Thermobarometry}

The $\mathrm{P}-\mathrm{T}$ equilibration conditions of peridotitic concentrate clinopyroxenes from the Mbuji-Mayi and Tshibwe kimberlites were estimated using the clinopyroxene thermobarometer of Nimis and Taylor (2000). Based on these $\mathrm{P}-\mathrm{T}$ estimates, clinopyroxenes from Mbuji-Mayi and Tshibwe define a compositional and thermal profile through the northeastern Kasai craton to depths as great as 220 $\mathrm{km}$, a depth consistent with previous thermobarometry and geophysical studies (Batumike et al., 2009; Crosby et al., 2010). The two kimberlites sampled and entrained clinopyroxenes from a pressure and temperature interval between 26 and $72 \mathrm{kbar}$ and 967 to $1264{ }^{\circ} \mathrm{C}$. However, the continental lithospheric mantle beneath Tshibwe, on average, was cooler (with an average thermal gradient of $20^{\circ} \mathrm{C}$ per $\mathrm{kb}$ ) than at Mbuji-Mayi (with an average thermal gradient of $26^{\circ} \mathrm{C}$ per kb) (Fig. 2b)

\section{Origin of clinopyroxenes}

Clinopyroxenes from Mbuji-Mayi and Tshibwe show typical peridotitic major element compositions, with high $\mathrm{Mg} \#$ and with $\mathrm{Cr}_{2} \mathrm{O}_{3}$ and $\mathrm{Al}_{2} \mathrm{O}_{3}$ concentrations that plot in the field associated with garnet-bearing lherzolites (Nimis, 1998). Moreover, the REE concentrations and profiles of Mbuji-Mayi and Tshibwe clinopyroxenes are also similar to those reported for diopsides from "type 1" metasomatised garnet lherzolites (Grégoire et al., 2003) from some Kaapvaal kimberlites.

Group 1 clinopyroxenes from Mbuji-Mayi have $(\mathrm{Sc} / \mathrm{V})_{\mathrm{N}}$ ratios lower than unity $(0.41-0.99)$, typical of clinopyroxenes from garnet lherzolites (Glaser et al., 1999; Barth et al., 2001). Therefore, the group 1 clinopyroxenes likely originated from metasomatised garnet lherzolite. Group $2 \mathrm{cpx}$ from Mbuji-Mayi and Tshibwe cpx have $(\mathrm{Sc} / \mathrm{V})_{\mathrm{N}}$ ratios greater than unity (with ranges of $1.01-2.19$ and $1.14-2.56$, respectively), suggesting derivation from a mantle lithology with little to no garnet present. This could indicate a highly infertile garnet lherzolitic or possibly a garnet-free peridotitic or pyroxenitic source.

Peridotitic garnets occur, though not abundantly, in the concentrate from these kimberlites. It is therefore likely that garnet lherzolite is the main lithology beneath the northeastern section of the Congo-Kasai Craton. The SCLM beneath Mbuji-Mayi appears to have a higher proportion of garnet lherzolite while the SCLM beneath Tshibwe appears to have a more garnet-depleted lithological character.

\section{Metasomatism}

Primitive mantle-normalised incompatible element patterns both in Tshibwe and Mbuji-Mayi clinopyroxenes show evidence of kimberlite-related metasomatism, which is supported by the large degree of Sr isotopic overlap between the clinopyroxenes and whole-rock ${ }^{87} \mathrm{Sr} /{ }^{86} \mathrm{Sr}$ values for MbujiMayi kimberlites (Weis \& Demaiffe, 1985). However, it appears that Mbuji-Mayi clinopyroxenes have undergone more extensive metasomatism (stronger LREE enrichment, higher overall incompatible element contents) than at Tshibwe. Therefore, the mantle sampled by the Mbuji-Mayi kimberlites appears to have been warmer and metasomatically more disturbed compared to the cooler and more depleted lithosphere sampled by the Tshibwe kimberlite cluster. The occurrence of different thermal and metasomatic states in mantle located in close proximity (within $35 \mathrm{~km}$ ) suggests that the Tshibwe cluster kimberlites may have been emplaced prior to Mbuji-Mayi (70 Ma) (Schärer et al., 1997) and prior to major thermal and metasmatic disturbance of the SCLM.

\section{Acknowledgements}

Support for this work was generously provided by the South African National Research Foundation to BJN and PEJ, and by the Society for Economic Geologists through a grant to BJN.

\section{References}


Barth, M.G., Rudnick, R.L., Horn, I., McDonough, W.F., Spicuzza, M.J., Valley, J.W., Haggerty, S.E., 2001. Geochemistry of xenolithic eclogites from West Africa, part I: a link between low $\mathrm{MgO}$ eclogites and Archean crust formation. Geochimica et Cosmochimica Acta 65, 1499-1527.

Batumike, J.M., Griffin, W.L., O'Reilly, S.Y., 2009. Lithospheric mantle structure and the diamond potential of kimberlites in southern D.R. Congo. Lithos 112 (S1), 166-176.

Crosby AG, Fishwick S, White N (2010). Structure and evolution of the intracratonic Congo Basin. Geochemistry Geophysics Geosystems 11: Q06010.

Glaser, S.M., Foley, S.F., Günther, D., 1999. Trace element compositions of minerals in garnet and spinel peridotite xenoliths from the Vitim volcanic field, Transbaikalia, eastern Siberia. Lithos 48, 263-285.

Grégoire, M., Bell, D.R., Le Roex, A.P., 2002. Trace element geochemistry of phlogopite- rich mantle xenoliths: their classification and their relationship to phlogopite- bearing peridotites and kimberlites revisited. Contributions to Mineralogy and Petrology 142, 603-625.

Grégoire, M., Bell, D.R., Le Roex, A.P., 2003. Garnet lherzolites from the Kaapvaal craton (South Africa): trace element evidence for a metasomatic history. Journal of Petrology 44, 629-657.

Nimis, P., 1998. Evaluation of diamond potential from the composition of peridotitic chromian diopside. European Journal of Mineralogy 10, 505 - 519.

Nimis, P., Taylor, W.R., 2000. Single clinopyroxene thermobarometry for garnet peridotites. Part I. Calibration and testing of a $\mathrm{Cr}$-in-Cpx barometer and an enstatite-in-Cpx thermometer. Contributions to Mineralogy and Petrology 139, 541-554.

Schärer, U., Corfu, F., Demaiffe, D., 1997. U-Pb and Lu-Hf isotopes in baddeleyite and zircon megacrysts from the Mbuji-Mayi kimberlite: constraints on the subcontinental mantle. Chemical Geology 143, 1-16.

Weis, D., Demaiffe, D., 1985. A depleted mantle source for kimberlites from Zaire: $\mathrm{Nd}, \mathrm{Sr}$ and $\mathrm{Pb}$ isotopic evidence. Earth and Planetary Science Letters 73, 269-277.
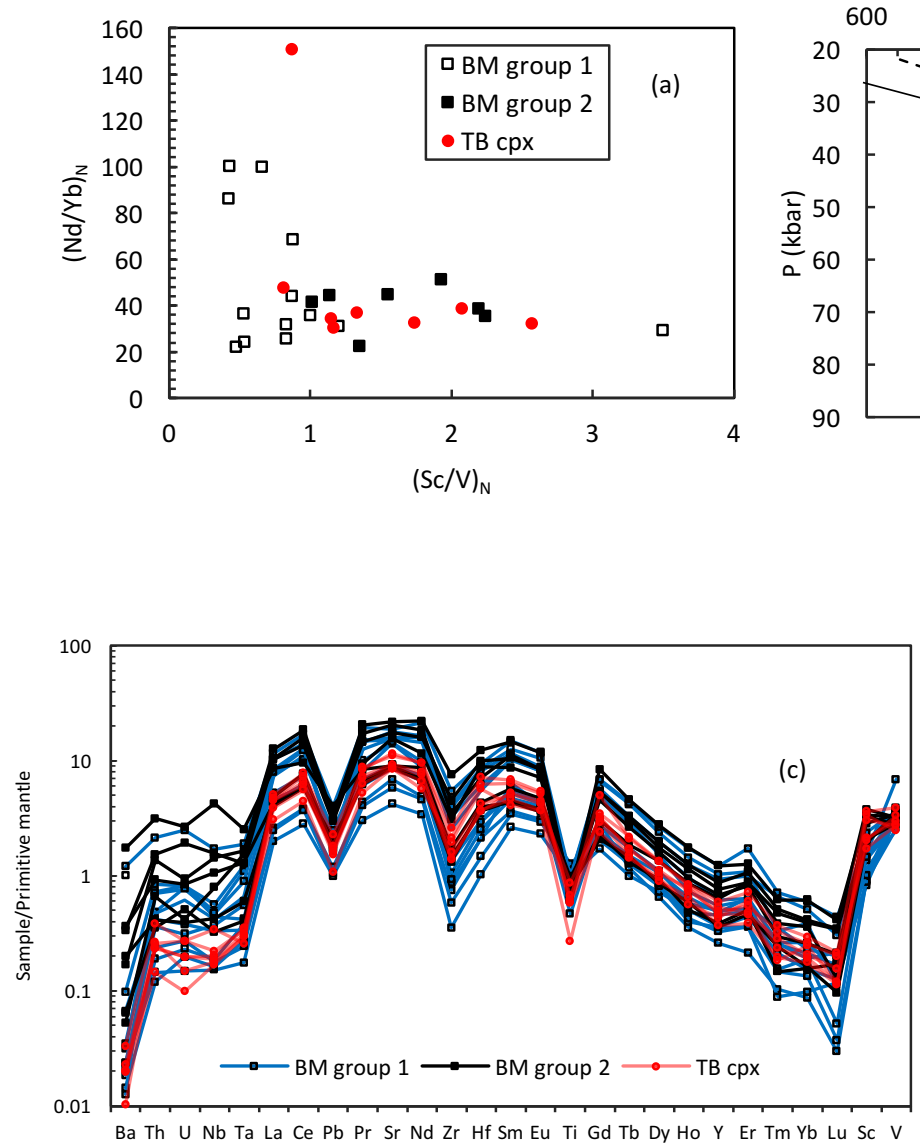

Figure 2: (a) $(\mathrm{Nd} / \mathrm{Yb}) \mathrm{n}$ vs $(\mathrm{Sc} / \mathrm{V}) \mathrm{n}$ plot. Note the distinct distribution of Mbuji-Mayi group 1 and Tshibwe/ Mbuji-Mayi group 2 cpx ; (b) $\mathrm{P}$ (kbar) vs $\mathrm{T}\left({ }^{\circ} \mathrm{C}\right)$ plot with values based on the Nimis and Taylor (2000) thermobarometer. $35 \mathrm{~mW} / \mathrm{m}^{2}$ geotherm is provided for reference;

(c) Primitive-mantle-normalized trace element patterns of MbujiMayi (BM group1 and group 2) and Tshibwe cpx (TB cpx). Normalizing values from McDonough and Sun (1995). 